\title{
Jednostka, społeczeństwo, demokracja w archetypie kultury polskiej: Jest problem czy go nie ma?
}

\author{
The Individual Person, Society, \\ Democracy in the Archetype of Polish Culture: \\ Is There a Problem or Not?
}

\author{
Wojciech Kaute*
}

\begin{abstract}
Abstrakt
U podstaw kultury europejskiej tkwi myśl Sokratesa, iż zasady życia społecznego muszą być tworzone w oparciu o ,istotę rzeczy". U progu czasów nowożytnych następuje zmiana tego paradygmatu. Jest to myśl Kartezjusza; cogito. Tu punktem wyjścia jest $J a$, jednostka podejmująca działalność ekonomiczną Th. Hobbes; J. Locke). Jednak rynek to nie wszystko (J.J. Rousseau, I. Kant). W archetypie kultury polskiej jest inaczej. Istnieje potrzeba uwzględnienia "wartości". I to jest imperatyw każdej jednostki; i jednocześnie wszystkich. Jest to, jak to ujął J. Lelewel, "taniec polski"; "tłum". I to jest archetyp kultury polskiej. Polska jest "wieczną czułością" (Y. Haenel). Czy jest to stano-
\end{abstract}

\begin{abstract}
At the foundation of European culture lies Socrates' idea that the rules of social life must be based on "the essence of things". At the threshold of modernity, this paradigm was replaced by Descartes' cogito, where the $I$ is the starting point: an individual person undertaking some economic activity (Th. Hobbes, J. Locke). However, the market is not everything (J.J. Rousseau, I. Kant). According to the archetype of Polish culture, things are different. It stresses the need to take into account "values", which is the imperative of every individual and at the same time of the community. In the words of Lelewel, this is "the Polish dance"; the "crowd". This is the archetype of Polish culture. Poland is "perennial tenderness"
\end{abstract}

* Wyższa Szkoła Ekonomiczno-Humanistyczna w Bielsku-Białej (wojciech.kaute@gmail. com); iD https://orcid.org/ 0000-0002-5092-7117 
wisko - w refleksji nad dziejami Polski - przekonywujące, to kwestia cały czas otwarta.

Słowa kluczowe: Sokrates, cogito, Th. Hobbes, J. Locke, J.J. Rousseau, I. Kant, Oświecenie, S. Brzozowski, S.I. Witkiewicz, W. Gombrowicz, Y. Haenel.
(Y. Haenel). Whether this may be a convincing position in reflections upon Polish history still remains an open question.

Keywords: Socrates, cogito, Th. Hobbes, J. Locke, J.J. Rousseau, I. Kant, the Enlightenment, S. Brzozowski, S.I. Witkiewicz, W. Gombrowicz, Y. Haenel

Od pokoleń, jednym z podstawowych problemów kultury polskiej była i jest kwestia odpowiedzi na pytanie o relację: Polska a Europa. Co stanowi przesłankę powyższego pytania? Tą przesłanką jest - mniej lub bardziej expressis verbis deklarowane - przekonanie, iż archetyp kultury polskiej w konfrontacji $\mathrm{z}$ „duchem nowożytności” wykazuje pewną specyfikę. W tym stanie rzeczy, jak o tym pisał przed laty wybitny historyk łódzki Jan Adamus, istnieje potrzeba wyjaśnienia, jak to ujął, „tej głównej zagadki dziejów Polski” (Adamus 1958, s. 280). Co do tego przekonania wszak zdania były i są podzielone. Wedle jednej grupy opinii, nie ma żadnej „zagadki”... Jesteśmy w Europie; i tyle... Rzecz w tym, iż w chaosie polskiego życia publicznego problem nieustannie powraca. Jeżeli, z kolei, przyjmie się, iż on istnieje, i to całkiem realnie, wszystko zaczyna się komplikować. Zdania bowiem na temat tego, w czym wyraża się wspomniana specyfika, były zawsze i są niejednoznaczne w swej wymowie. A więc: jest problem, czy go nie ma? A jeżeli jest, to co robić? - oto istota zagadnienia...

$* * *$

Kultura europejska w swojej dwuipółtysiącletniej tradycji wypracowała określony sposób myślenia, filozofię i jej kategorie; język. Leszek Kołakowski, w napisanej i wydanej na Oxfordzie u schyłku XX wieku książeczce pod wymownym tytułem Horror metaphysicus, w jej pierwszych słowach napisał: „Od wieków filozofia utwierdzała swą prawomocność, stawiając i odpowiadając na pytania odziedziczone z sokratejskiej i przed-sokratejskiej spuścizny: jak odróżnić rzeczywiste od nierzeczywistego, prawdę od fałszu, dobro od zła. Jest jeden człowiek, z którym identyfikują się wszyscy europejscy filozofowie, choćby nawet w całości odrzucali jego idee. Jest to Sokrates - filozof niezdolny utożsamić się z tą archetypiczną postacią nie należy do tej cywilizacji” (Kołakowski, 1990, s. 7). Sokrates, jak przekazuje Ksenofont, ,zawsze, kiedy rozważał sprawy ludzkie, starał się zbadać, czym w swej istocie jest pobożność, a czym bezbożność, czym piękno, a czym brzydota, czym sprawiedliwość, a czym niesprawiedliwość, czym rozsądek, a czym szaleństwo, czym męstwo, a czym tchórzostwo, czym państwo, a czym mąż stanu, czym władza nad ludźmi, a czym władca; 
i podobnie rozprawiał o istocie innych rzeczy. Ci, którzy zdobywali tego rodzaju wiedzę, w jego mniemaniu stawali się ludźmi moralnie doskonałymi, ci natomiast, którzy nie mieli o tym wyobrażenia, zasługiwali na miano dusz niewolniczych” (Ksenofont, 1967, I, 1, 2-5). Świat „wartości” ma walor obiektywny...

Problem w tym - a to jest kwestia dla niniejszych rozważań fundamentalna - iż ten sposób rozumowania u progu czasów nowożytnych uległ kontestacji. Dokona tego myśl Kartezjusza. Ego cogito, ergo sum. Ja to Ja. Było to, wbrew temu, co się wydaje na pierwszy rzut oka, dwuznaczne odkrycie. Jak pisze Kołakowski w przywołanej pracy, „Kartezjusz odkrył wewnętrzny świat nie po to, by przemienić go w boskie podłoże bytu; miał on być etapem końcowym. Odsłaniał się ów jedyny świat samo-przejrzysty, a zarazem również samo-tożsamy co Absolut, ale inaczej niż Absolut dostępny wprost, a nie w wyniku abstrakcyjnego rozumowania. Kartezjańskie ego istotnie jest w tym sensie absolutem, że będąc zawsze jedynym i wyjątkowym, nieprzeniknienie i wsobnie moim, może zawsze powiedzieć, jak biblijny stwórca, »jestem, który jestem«. »Ja« jestem czystą aktualnością, ponieważ w każdym »teraz« jestem wszystkim, czym mogę być" (Kołakowski, 1990, s. 83). Ja myśli. Jeżeli coś nie jest przedmiotem tego myślenia, to to coś nie istnieje. U progu nowożytności wszelkie „wartości” okazują się predykatami „świata” Ja. Czym jest ten „świat”? - zadaje pytanie współtwórca doktryny liberalizmu Thomas Hobbes. I odpowiada: jest to ,żądza mocy” („desire of power”) (Hobbes, 1954, s. 64). A czym jest ta „żądza”? Jest to chcieć żyć; przetrwać. A to oznacza tyle, co podporządkowanie sobie otoczenia, przyrodniczego i społecznego. Jednostka z natury jest ,wilkiem”. Rzecz w tym, iż to wyjściowe $J a$ w swym działaniu natrafia na nie- $J a$, które ma na uwadze to samo. „Żądza mocy” trafia na ,żądzę mocy”; „wilk” na „wilka”. Co zatem robić w świecie bellum omnium contra omnes? Stwórzmy państwo, odpowiada Hobbes. Państwo to coś, co tworzy prawo. A co to jest prawo? Jest to coś całkiem prozaicznego; ustawy, uchwały, rozporządzenia... Lewiatan to, jak to ujęto w literaturze przedmiotu, ,sztuczna Opatrzność” (Manent, 1994, s. 53). Ten sposób myślenia domknie John Locke. Każda jednostka, chcąc utrzymać się przy życiu, twierdzi Locke, musi podjąc wysiłek wykorzystania dóbr natury, czyli pracę. Efekty pracy jednostki należą - z definicji - do niej. Co decyduje o wielkości tych efektów? Decyduje o tym, jak to określa Locke, ,pierwsze zebranie” (,the first gathering”) (Locke, 1992, s. 182). "Zebrałem” żołędzie spod drzewa jako „pierwszy”; a więc są one przedmiotem mojego prawa własności. „Zebrałem” dużo, jest mnie dużo; ,zebrałem” mało, jest mało; nie ,zebrałem” nic, nie ma mnie. Jednostka to tyle, co jej ,przedsiębiorczość"; i jej efekty. To jednak nie koniec. Jest bowiem tak, iż nikt nie ma wszystkiego. Poza tym można ,zebrać” powyżej własnych potrzeb; efekty „przedsiębiorczości” zmarnują się. „Zebrałem” żołędzie, ale nie mam jabłek, które, z kolei, ty masz, choć nie masz żołędzi; nadto żołędzi mogę mieć w nadmiarze, jak ty - jabłek. I tak pojawia się coś, co rozwiązuje wszelkie problemy; pieniądz. Żyje się, produkuje, wymienia... 
Ten stan rzeczy zrodzi w kulturze europejskiej bunt. Zgłosi go Jean-Jacques Rousseau. Otwierając pierwszy rozdział Umowy społecznej (1762) Rousseau pisze: „Człowiek urodził się wolny, a wszędzie jest w okowach” (Rousseau, 2002, s. 11). Jak to jest możliwe? W świecie rynku, jak relacjonuje myśl Rousseau Pierre Manent w pracy Intelektualna historia liberalizmu, jednostka „W stosunkach z innymi myśli wyłącznie o sobie, a w swoich stosunkach ze sobą myśli wyłącznie o innych" (Manent, 1994, s. 101). Ja myślę o Tobie tylko jako o właścicielu tego, czego Ja nie mam. A i o sobie myślę tylko jako o właścicielu tego, czego mam w nadmiarze. I taka sama jest twoja sytuacja. W świecie nowożytnego rynku nie spotyka się człowiek z człowiekiem, a - wymieniane przy pomocy pieniądza i „rządzące” nim - rzeczy. I to są te „okowy”. Rousseau, tęsknym okiem spoglądając w świat sprzed cogito, tworzy nową - na miarę nowej sytuacji - koncepcję jednostki. Tym, co należy do ,istoty” tej jednostki, jest „litość” (pitie) (Rousseau, 1956, s. 173); „litość” wobec drugiego. Rousseau, jak pisał przed laty Bronisław Baczko, kartezjańskie myśle więc jestem, zamienia na „,czuje, że jestem” (Baczko, 1964, s. 386). Tu decyduje „racja serca” (Baczko, 1964, s. 387). „Człowiek z natury jest dobry” (Rousseau, 1956, s. 243). I tym tropem rozumowania pójdzie Immanuel Kant. Kant w całej pełni podziela obiekcje Rousseau skierowane pod adresem rynku. Jak zauważał cytowany tu już autor, „Kant pisał, że [...] lektura Rousseau »przywróciła go prawdzie«. Można powiedzieć, że całe dzieło Kanta, zwłaszcza w swej partii etycznej, powstało z inspiracji Russowskiej” (Baczko, 1964, s. 723). A jednak sposób myślenia Rousseau Kantowi nie odpowiada. Jest to, jak pisze, przejaw tego, co on określa jako „dobroduszne założenie moralistów" (Kant, 1993b, s. 40). Człowiek jest taki, jaki jest. Można go nazwać „dobrym”, ale to tylko tautologia.

Całokształt poznania człowieka, jednostki - twierdzi w punkcie wyjścia swojego konceptu Kant - to świat a priori. To a priori jednak, wedle niego, ma „umocowanie” w - jak to określa - „przyrodzie”. O świecie można mówić jedynie jako o „danych” ludzkiego doświadczenia. Jest to „ludzkie”; i jednocześnie zgodne z obiektywną rzeczywistością. W efekcie trzeba przyjąć, pisze Kant w pracy, która mogłaby stanowić streszczenie całej jego filozofii, Prolegomena do wszelkiej przyszłej metafizyki, która będzie mogła wystapić jako nauka: „[...] choć brzmi to początkowo dziwnie, lecz jednak jest pewne [...]: Intelekt nie czerpie swych praw (a priori) z przyrody, lecz je przyrodzie dyktuje" (Kant, 1993a, s. 107). Jednakże dyktuje on je jej, pod jej dyktando. I całokształt tego rozumowania odnosi Kant do całokształtu życia społecznego. W postępowaniu każdej jednostki część tego postępowania opiera się na tym, co dla niej jest indywidualne. Są to, wedle określenia Kanta, maksymy; ,zasady praktyczne” (Kant, 2002, s. 37) jej życia... Druga część opiera się na tym, co powszechne, intersubiektywne. Są to, wedle jego terminologii, prawa. Z maksym nie da się zrobić prawa. Nie da się. A jednak trzeba. Umożliwia to czysto formalna zasada, sucha formuła. „Postępuj tak, żeby maksyma twej woli zawsze mogła 
być uważana zarazem za zasadę powszechnego prawodawstwa" (Kant, 2002, s. 46). W praktyce oznacza to tyle: „Postępuj tak, byś człowieczeństwa tak w twej osobie, jako też w osobie każdego innego, używał zawsze zarazem jako celu, nigdy tylko jako środka” (Kant, 1953, s. 62). „Paradoksalność”, jak to określa Kant, polega tu na tym, „że pojęcie dobra $i$ zła musi być wyznaczone nie przed prawem moralnym (którego podstawe, jak się pozornie może wydawać, musiałoby nawet stanowić), lecz dopiero po nim i przez nie" (Kant, 2002, s. 74). I w tym wyraża się prawo-twórcza działalność człowieka. „Potrzeba czystego praktycznego rozumu oparta jest na obowiązku, nakazującym, abym coś (najwyższe dobro) uczynił przedmiotem swej woli i bym ze wszystkich sił starał się to pomnażać. [...] Obowiązek ten opiera się na czymś, [...], co jest samo przez się apodyktycznie pewne, [...] i nie wymaga żadnego dalszego poparcia przez teoretyczne mniemania, dotyczące wewnętrznych właściwości rzeczy, tajnych celów porządku świata lub zarządcy, który stoi na ich czele" (Kant, 2002, s. 141). Ja spełniam „obowiązek”; i Ty... Jak pisze Kant, „,notę jako gotowość do działań odpowiadających obowiązkowi (co do ich legalności) [można] nazwać virtus phaenomenon, ale tę samą cnotę jako trwałe usposobienie do takich działań z obowiązku (ze względu na ich moralność) [można nazwać] virtus noumenon" (Kant, 1993b, s. 35). Każde z nich daje inne rozumienie prawa. „Stan prawno-obywatelski (polityczny) jest to wzajemny stosunek ludzi, którzy zbiorowo podlegają ustawowym prawom (wszystkie one są prawami przymusu). Stan etyczno-obywatelski to ten, w którym ludzie zjednoczeni są równymi, wolnymi od przymusu, tj. czystymi prawami cnoty" (Kant, 1993b, s. 122).

I to jest „duch” Oświecenia. W znanym artykule Kanta Co to jest oświecenie? czytamy: „Oświeceniem nazywamy wyjście czlowieka $\mathrm{z}$ niepełnoletności, w którą popadł $\mathbf{z}$ własnej winy. Niepełnoletność to niezdolność człowieka do posługiwania się swym własnym rozumem, bez obcego kierownictwa. Zawinioną jest to niepełnoletność wtedy, kiedy przyczyną jej jest nie brak rozumu, lecz decyzji i odwagi posługiwania się nim [...]. Sapere aude! Miej odwagę posługiwać się swym własnym rozumem - tak oto brzmi hasło oświecenia" (Kant, 1995, s. 53). Gdzie tkwi tego przyczyna? Są to „lenistwo i tchórzostwo”, odpowiada Kant, „dla których tak wielka część ludzi, mimo wyzwolenia ich przez naturę $\mathrm{z}$ obcego kierownictwa [...] pozostaje chętnie niepełnoletnimi przez całe życie” (Kant, 1995, s. 53). Czego zatem potrzeba? „Nie potrzeba niczego prócz wolności [...], wolności czynienia wszechstronnego publicznego użytku ze swego rozumu” (Kant, 1995, s. 54) - odpowiada Kant. „Wolność” to „rozum”; „rozum” to „,wolność”. „Człowiek może wprawdzie, jeśli chodzi o jego własną osobę, odsunąć, i to tylko na jakiś czas, konieczność oświecenia się co do tego, o czym powinien wiedzieć - ale zrezygnować z oświecenia w ogóle w odniesieniu do własnej osoby, a tym bardziej w odniesieniu do potomności - znaczy gwałcić i deptać nogami najświętsze prawa ludzkości” (Kant, 1995, s. 58). „Jeśli więc teraz kto zapyta: czy żyjemy obecnie w oświeconej epoce? 
odpowiedź brzmieć będzie: Nie, ale w epoce oświecenia" (Kant, 1995, s. 58). Świat a priori, „rozumu”, „odwagi” to wielka nadzieja człowieka...

Gdzie tu Polska? Literatura na temat polskiego archetypu jest ogromna; opisywano go, i tak jest także dzisiaj, na rozmaite sposoby. Jak wolno sądzić, w tej literaturze na szczególną uwagę zasługuje twórczość Joachima Lelewela. Wśród wielu jego dzieł przede wszystkim wyróżniają się Uwagi nad dziejami Polski i ludu jej, pisane na emigracji w latach 30. XIX wieku, w Polsce wydane (jeszcze z dwiema innymi pozycjami) w Poznaniu, w książce Polska, dzieje i rzeczy jej, w 1855 roku. W latach 50., 60. i 70. Instytut Historii PAN wydał dziewięć, szczegółowo opracowanych, tomów prac Lelewela. Zabrakło wśród nich Uwag... Do dzisiaj nie zostały one „przetłumaczone” ze staropolszczyzny na język współczesny. We wprowadzeniu do Uwag..., w ustępie streszczonym: $W$ sprzecznym kole świata co począć, Lelewel pisze: „Potomność, jeżeli nie zapłacze, surową będzie w ocenianiu rozumu wieku naszego: a my pytać się możemy siebie, przy pięknych słowach, dokąd dążymy? Wiek oświecenia, cywilizacji, postępu, wynalazków, nowych postrzeżeń, wzniosłych pomysłów, toczy się w opacznym kole. [...] Filantropy, by użyć świata, obliczają dozy pożywnych pierwiastków, szpitale, domy przytułku lub choroby, służą do wypróbowania, co szkodliwe, co trucizną; pod niebiosa wynoszą i swą czcią okadzają zachwalaną pracę, obliczają ludzkie zdolności, a wycieńczają siły przy warsztatach; boleją nad ubóstwem, a w czułości swej wynajdują środki pozbawiające. [...] Ludzkość wymaga ocalić winowajcy życie, ochronić go od cielesnych cierpień, ale wymyśla torturę moralną, zgnębienie umysłu. [...] Przemysł protegowany: ruszajże błąkać się w odmęcie zawad, przepisów, zastrzeżeń, formalności, utrudzeń. Mnoży się gałganów na świecie, a nie ma ich dosyć na wyroby potrzebnego papieru [...] Cywilizacja woła, skruszyć niewolę, wyzwalać, równość między ludźmi, a na wszystkie zastawki kuje pęta i więzy, aby w powszechnym więzieniu wszyscy się w nich zarówno rozlubowali" (Lelewel, 1855, s. V, 20-21). Rynek to nie wszystko... Lelewel o roussowskiej koncepcji człowieka wypowiada się zawsze $\mathrm{z}$ entuzjazmem. A jednak jego ocena 1789 roku, wyrosłego wszak z „ducha” Rousseau, nie jest jednoznaczna. „Rewolucja! straszny wyraz! Francja uczyniła go takim, gdy [...] po raz pierwszy skruszyła więzy powszechnego despotyzmu” (Lelewel, 1864, s. 83). „Litość” i gilotyna to pojęcia wykluczające się... A już stanowisko Kanta jest dla Lelewela całkowicie niedopuszczalne; jest ono takie z przyczyn zasadniczych... „Choć idealiści wychodzili od swego umysłu, zawsze jednak musieli się kręcić koło przedmiotów, na które się zwracali. Kant, odwrotnie, kazał się przedmiotom około filozofa kręcić" (Lelewel, 1964, s. 835). Myśl Kanta jest absurdem... „Przedmiot” to „przedmiot”; „wartość” nie jest predykatem $J a \ldots$ „Co z tego wyniknie potomność wiedzieć będzie. A nam dalej swego szukać" (Lelewel, 1855, s. 22).

Na Kancie wszak dylematy „ducha” nowożytnego - który w świecie cogito próbuje wyjść poza sferę predykatów $J a$ - nie kończą się. Kantowskie a priori - 
przypomnijmy - aczkolwiek takie jest, to jednocześnie takie... nie jest; ma Ono „umocowanie”; w „przyrodzie”. Z tego stanu rzeczy ostateczne konsekwencje wyciągnie Fichte. W monumentalnej pracy Kołakowskiego Gtówne nurty marksizmu. Powstanie - rozwój - rozkład czytamy „Johann Gottlieb Fichte - był tym, który kantowską naukę o wolności jako powołaniu ducha ludzkiego chciał uwolnić od ograniczeń a przez to zarysować punkt widzenia, w którym możliwościa, a także powinnościa człowieka jest radykalna samowiedza swego nieograniczonego zwierzchnictwa nad bytem, bezwzględna zaczątkowość własnej egzystencji, bezwzględny brak ograniczenia ze strony jakiegokolwiek zastanego ładu" (Kołakowski, 1988, s. 47). Jest to jego koncepcja Ja transcendentalnego; wizja ludzkości - rozumianej in toto - podejmującej, w nigdy niekończącym się „,zynie”, wysiłek uczłowieczenia świata. Myśl nowożytna wszak na tym nie poprzestała. W myśli Kanta punktem odniesienia było to, co szczególne, świat jednostki; w myśli Fichtego to, co ogólne... Jednakże, jak pisze Kołakowski, „W obu przypadkach nie została [...] pokonana alternatywa: albo duch spotyka się z przypadkowościa bytu, a przez to sam, jako poznający, nieuchronnie zaraża się, by tak rzec, przypadkowością, albo znosząc przypadkowość, znosi zarazem rozmaitość bytu" (Kołakowski, 1988, s. 52). Zsyntetyzowanie obu stanowisk złoży się na dzieło Georga Wilhelma Friedricha Hegla. Wedle niego taka synteza jest możliwa pod warunkiem, że przyjmie się określony punkt widzenia. Ma się on wyrażać w tym, iż „nasz rozum, kiedy rozmyśla o stawaniu się absolutu, musi samą swoją czynność ująć jako składnik tego właśnie stawania się. [...] Nasze myślenie o świecie jest [...] [wówczas] świadome tego, że stanowi fragment stawania się tegoż świata, że jest dalszym ciągiem tego właśnie, do czego się odnosi. Hegel nie pisze o duchu: pisze autobiografię ducha" (Kołakowski, 1988, s. 54). Sytuacja przeciwna, właściwa kulturze sprzed jego wystąpienia, to taka, jak relacjonuje myśl Hegla Kołakowski, kiedy mamy do czynienia ze „świadomością nieszczęśliwą, doświadczającą rozdarcia na siebie jako byt samoistny i siebie jako byt przypadkowy" (Kołakowski, 1988, s. 58). A zatem, jeżeli chce się „ocalić zarówno samoistność ducha, jak wielorakość bytu [...], to możliwe jest [...] nie po prostu przez ogłoszenie dowolnej definicji ducha, która by te warunki spełniała, ale przez opis historyczny, w którym zawarty będzie cały rozwój bytu, zdolny do ogarnięcia jednolitym sensem dziejów świata, nade wszystko dziejów kultury ludzkiej. Historyczny ów system ma więc przedstawić dorastanie ducha, przez mękę dziejów, do postaci absolutnej. Opis ten zawiera Fenomenologia ducha..." (Kołakowski, 1988, s. 53). I ten sposób myślenia stworzy punkt wyjścia koncepcji Karola Marksa. Wedle Marksa koncept Hegla, jak to ujmuje w Postowiu do drugiego wydania Kapitału, „stoi na głowie” (Marks, 1968, s. 19). A to dla niego oznacza, iż trzeba go „postawić na nogi” (Marks, 1968, s. 19). Te „nogi” - czyli Marksowska teoria wartości, wartości dodatkowej - wpisane wszak są u niego w ramy heglowskiej teodycei, choć, jak podkreśla się w literaturze przedmiotu, próbował on ją ukryć „pod 
fasadą naturalistyczno-scjentystyczną" (Walicki, 1996, s. 53). Co na to Lelewel? „Innym zawadzają cudze własności, zupełnej wspólnoty wymagają. Nowa mówią idea: niepomni wiele to [...] kapturów w swoim czasie bracia świętego Franciszka oberwali w zwadach o to, czy już ich jest własnością to, co w ustach do połknięcia mają" (Lelewel, 1855, s. 20).

W archetypie kultury polskiej nie ma zgody na liberalizm; a i każda rewolucja to „straszny wyraz”. I nie ma zgody na sapere aude!; ani w wersji Kantowskiej, ani Fichteańsko-Heglowskiej; ani także ujętej w ekonomiczny sztafaż „świadomości nieszczęśliwej”, jaką przedstawia „Kapitał” Marksa. A więc jeżeli żadne z nich, to co? Pisze Lelewel w przywołanym tu już dziele: „Sądzę, że rozpatrzenie początku, wzrostu i urządzenia się rzeczypospolitej, dostatecznie zapewnia, że nie nadzwyczajny człowiek jaki, nie przesławna czyja wysoka zdolność dźwignęła wspaniały gmach [...]. Pojedyncze osoby tonęły w działaniu powszechnym tłumu; przeważne wpływy nikły, wynurzając się w następstwach; dzieje nie umieją dać sprawy z ich zabiegów, wysuwają tylko dużo imion porwanych w tłumną dążność. Tłum działa jak wichura, w której odmęt tylko, po jego jednak przelocie, spełzł dawny, nowy jaśnieje porządek; wyszumi się i znowu z większym trzaskiem huknie. Imiona pojedyncze chwilowo błyszczą i gasną, wichura sama huczy. [...] Powoduje głównie myśl, która unosi znamienitą część ludu, pojęcia, jakie powziął, które do pewnej dojrzałości rozwija” (Lelewel, 1855, s. 172-173). Czytamy u Lelewela: „Kiedy mówię, że lud polski tańcuje, mówię o jego tańcu narodowym. Lud bowiem dochowuje taniec ten sam, jaki jest znany szlachcie, [...] a wynika z jednostajnych narodowych usposobień. Taniec polski [...], taniec rozhoworu i wrzawy, uprzejmej towarzyskiej rozmowy, zakręca się i rozwija; zwalnia lub przyśpiesza kroku z małym w takt podrygiem. W długiej par kolei, pierwsza para rej wodzi, przewodzi. Klaśnienie zmieni w niej przewodnika, a gdy z odmętu ona wyprzodkuje wszystko za nią kołuje w porządku” (Lelewel, 1855, s. 284, przyp. 7). „Tłum”, „odmęt”, „wichura", „huk"...

Przed laty ks. Józef Tischner opublikował głośny artykuł, pod wymownym tytułem: Chochoł sarmackiej melancholii. „Chochoł z Wesela Wyspiańskiego [...]. Jest to w pełnym tego słowa znaczeniu symbol. Tworzywem chochoła jest słoma - suchy badyl pozbawiony ziarna. Kształtem i ruchem przypomina człowieka. W dramacie Wyspiańskiego pojawia się jako znak i zapowiedź ogarniającej weselnych gości apatii. [...] Czas stoi...” (Tischner, 1970, s. 1243). Jest to, jak określa Tischner, „nastrój”, któremu nadaje on nazwę: „sarmacka melancholia” (Tischner, 1970, s. 1243). Ten świat ma dwie warstwy. „Świat melancholii jest podzielony na dwie zasadniczo różne przestrzenie: górną, idealną i utopijną, oraz dolną, codzienną i prozaiczną. W idealną przestrzeń świata kierują się najgłębsze nadzieje, ambicje, marzenia człowieka. [...] W przestrzeni prozaicznej dzieje się szara codzienność, narodowa, społeczna i indywidualna alienacja" (Tischner, 1970, s. 1244). „Mówi się: jest, jak jest” (Tischner, 1970, s. 1245). 
W tym świecie rozum jest na dalszym planie. „Korelatem rozumu jest racjonalny porządek. Rozum wierzy w istnienie tego porządku i zmierza do jego opisu. Korelatem mentalności sarmackiej melancholii jest Przypadek. Ona wierzy przede wszystkim w Przypadkowość świata i zmierza do oparcia się o nią. Chwyta ona świat poprzez pryzmat gramatyki paradoksu, w której zasadniczo obowiązuje tylko jedna wartość logiczna: prawdopodobieństwo. Mamy tutaj do czynienia z jakąś negacją rozumu” (Tischner, 1970, s. 1249). Chochoł „wybierając melancholię jako sposób istnienia, wybiera [...] zdegradowane przeżywanie istnienia" (Tischner, 1970, s. 1253). Dziwna to sytuacja, twierdzi Tischner. Jest bowiem tak, iż w tym apatycznym stanie, jak pisze, „sarmatyzm wnosi ze sobą rys »zadzierżystości«, a zadzierżystość to niezręczna imitacja odwagi” (Tischner, 1970, s. 1245). W niej „obok wyłącznie instynktownych reakcji daje się także wykryć ukryty zamiar imponowania innym” (Tischner, 1970, s. 1245). Przywołuje Tischner Gałczyńskiego: „Bo jestem Polak. A Polak to wariat, a wariat to lepszy gość" (Tischner, 1970, s. 1251). Ponad sto lat temu w Legendzie Młodej Polski Stanisław Brzozowski pisał: ,Żaden Hume ani Nietzsche nie zdobyli się nigdy na tyle sceptycyzmu, ile go ma wobec wszystkich idei, wszystkich nauk, wobec literatury i sztuki, świata całego, przeciętna polska matka domu i dobra gospodyni, kochana, najzacniejsza Marynia Połaniecka" (Brzozowski, 1983, s. 53). I tak to, „W razie ataku na beztroskliwość, lekkomyślność, próżniactwo wywoływano wnet krwawe i żałobne mary [...] Wnet więc powołanie na niesprawiedliwość losu, łza kapiąca na wąsy" (Brzozowski, 1983, s. 91). Tym, co charakteryzuje świat, o jakim mowa, jest - jak to określi Witkacy - „uśmiech kretyna” (Witkiewicz, 1979, s. 333). „Kretyn musi też żyć, tzn. uznawać samego siebie, i aby zlekceważyć wszystko, co może go zaniepokoić, i to zlekceważyć w imię tradycji, sensu, zdrowego rozsądku, normalności, przeciętności itp., wynalazł [ten] cudowny środek" (Witkiewicz, 1979, s. 333). Ta sytuacja prowadzi „do wyśmiewania się z bezinteresownej walki o idee, do zakatrupienia w zarodku każdej samodzielnej myśli, do ogólnego spsienia i zgównienia wszystkiego; kretyn pokryje swym uśmiechem wszystko; uśmiech ten zaraźliwszy jest od dżumy” (Witkiewicz, 1979, s. 335). Polska, świat „szarej ćmy szlacheckiej” (Witkiewicz, 1979, s. 266), „nadęta hołota” (Witkiewicz, 1979, s. 262).

Polska. Wspomina Gombrowicz: „Byłem Polakiem. Znajdowałem się w Polsce. Czymże jest Polska? Jest to kraj między Wschodem a Zachodem, gdzie Europa już poczyna się wykańczać, kraj przejściowy, gdzie Wschód i Zachód wzajemnie się osłabiają. [...] Żaden z wielkich procesów kultury europejskiej nie przeorał naprawdę Polski, ani renesans, ani religijne walki, ani rewolucja francuska, ani rewolucja przemysłowa; tu tylko złagodzone echa dochodziły. A współczesna rewolucja rosyjska też nie została przeżyta, tylko skutki jej dostały się (przymusowo) Polsce, już gotowe. Katolicyzm? Kraj jest wprawdzie w orbicie Rzymu, ale polski katolicyzm jest bierny, polega na ścisłym prze- 
strzeganiu katechizmu, nigdy nie był twórczą współpracą z Kościołem. Na tych więc równinach, otwartych na wszystkie wiatry, [...] [wszystko] rozmazywało się [...], rozłaziło... Tu kultura była równinna, wiejska, pozbawiona wielkich miast, silnego mieszczaństwa, gdzie życie się skupia, komplikuje, piętrzy, nabiera rozmachu, zasila tysiącem splotów międzyludzkich. Była szlachecko-chłopska, proboszczowska. [...] Gdzież była polska myśl oryginalna, polska filozofia, polski udział intelektualny w tworzeniu Europy? [...] Literatura od stu pięćdziesięciu lat była zakorkowana dramatem utraty niepodległości, sprowadzona do lokalnych nieszczęść” (Gombrowicz 1992, s. 45). „Na niebie polskim tym niebie omdlewającej, kończącej się Europy, zbyt wyraźnie widać jak skrawki papieru nadlatujące $\mathrm{z}$ Zachodu zniżają lot by osiąść $\mathrm{w}$ błocie, na piasku iż by jedynie chłopaki pasące krowy mogły z nich zrobić wiadomy użytek" (Gombrowicz, 1992, s. 46). Szlachta, „rozpaczliwa banda gnuśnych bęcwałów” (Gombrowicz, 2013, s. 499).

Jak się jednak okaże, sytuacja nie jest taka jednoznaczna. Gombrowicz w Paryżu; początek lat 60.; środowisko literackie. „Zapytałem ich, kim jest X, którego znałem tylko ze słyszenia. Odpowiedziano, że wybitny pisarz. Powiedziałem, że, owszem, pisarz, ale kim jest? Wyjaśnili, że wywodząc się z surrealizmu oddał się ostatnio specyficznemu obiektywizmowi. Rzekłem, że, doskonale, obiektywizm, ale kim jest? Powiedziano że należy do grupy Melpomeny. Odpowiedziałem, że zgadzam się na Melpomenę, ale kim jest? Odparli, że jego gatunek charakteryzuje kombinacja argot z metafizyką ufantastycznioną. Mówię tedy, że zgadzam się na kombinację, ale kim jest? Na co odpowiedzieli, że cztery lata temu przyznano mu Prix St. Eustache" (Gombrowicz, 2013, s. 774775). Gombrowicz, siedząc w restauracji, uzupełnia swoje spostrzeżenia: „Pojąłem mój nietakt, cóż cię obchodzi kim jest twój kucharz, przecie nie kucharza zjadasz, a jego potrawy. I, nawiasem mówiąc, był to nietakt tyleż wobec kucharzy, co wobec krawców, gdyż pytanie »kim się jest« z natury swojej jest obnażające [...]. Literat francuski nie będzie przecież paradował nago, w powietrzu tutejszym unoszą się tysiące płaszczów, wyciąga się rękę, chwyta się płaszcz najbardziej przypadający do gustu [...]... powietrze roi się od technik, kierunków, rozwiązań, płaszczyzn, platform, powietrze paryskie jest ożywcze i lekkie, jak wóz z meblami" (Gombrowicz, 2013, s. 775). Ciągnie dalej Gombrowicz: „Nagość moja, [...] nagość [...] nie pozwalała mi nie być z nimi obnażającym. Wytworzyła się nieprzyzwoitość. Z jakimż zażenowaniem te tuzy przyjmowały mój wzrok namiętnie naiwny, dobierający się do nich poprzez ubranie... [...] Panuje skromność i rozwaga. Nikt nie narzuca się nikomu. Każdy robi swoje. Produkują i funkcjonują. Kultura i cywilizacja. Uwięzieni w stroju, ledwie się mogą ruszać, podobni do owadów posmarowanych czymś lepkim. Kiedy zacząłem zdejmować spodnie powstał popłoch, dawaj drała drzwiami i oknami. Pozostałem sam. Nikogo nie było w restauracji, nawet kucharze uciekli... [...] Wtem Kot [Konstanty A. Jeleński] wchodzi z ulicy i widząc mnie tak stojącego 
pyta ze zdumieniem: Oszalałeś, tobie się w głowie pomieszało, gdzie by tu kto się twojej nagości przestraszył, przecie na całym świecie nie znajdziesz takiego zdzierania szat, jak tutaj... czekaj, na królików trafiłeś, ale ja ci sproszę lwów takich, że choćbyś goły na stole tańczył, ani mrugną! Stanął tedy zakład między nami, zakład szlachecki i polski. [...] No, dobra! Sprosił kogo trzeba, intelekty najbrutalniej obnażające, ja nic, aż kiedy już do wetów przyszło, zaczynam portki zdejmować. Zwiali, grzecznie przeprosiwszy, że niby czas na nich! Mnie ciężko bardzo i źle na duszy, [...] mało brakowało, a byłbym gorzko się rozpłakał, ale mówię: - Cała rzecz w tym, że oni, uważacie, nawet rozbieraniem się ubierają i nagość to u nich tylko jedna paru pantalonów więcej. Ale jak ja tak zwyczajnie portki spuściłem, to ich zemgliło, a głównie dlatego, żem nie zrobił tego wedle Prousta, ani à la Jean Jacques Rousseau, ani wedle Montaigne'a czy w sensie egzystencjalnej psychoanalizy, tylko ot tak sobie, byle zdjąć" (Gombrowicz, 2013, s. 775-776).

A oto inny fragment Dziennika.. Luwr... „Tłok na ścianach, wywieszenie tych obrazów głupie, jeden obok drugiego. Czkawka tego nagromadzenia. Kakofonia. Karczma. Leonardo bije się po pysku z Tycjanem. Zez tu wszechwładnie panuje, bo gdy patrzysz na jedno, drugie włazi ci w oko z boku... Chodzenie od jednego do drugiego, stawanie, przyglądanie się, obchodzenie, podchodzenie, stawanie, przyglądanie się. Światło, barwa, kształt, którymi cieszyłeś się jeszcze przed chwilą, na ulicy, tu krzyżując się w rozłamaniu na tyle wariantów włażą ci w gardło [...]. Aż w końcu dochodzisz do świętego zakątka, gdzie króluje ona, Gioconda! Witaj, Cyrce!... [...], niezmordowanie przemieniająca ludzi, nie w świnie wprawdzie, a w cymbałów! [...] Codziennie od pięciu wieków gromadzi się przed tym obrazem tłumek aby doznać kretyńskiego rozdziawienia gęby, ta sławna twarz codziennie ogłupia im twarze... pstryk! Amerykanin z aparatem fotograficznym. Inni uśmiechają się pobłażliwie w błogiej niewiedzy, że ich kulturalna pobłażliwość jest nie mniej głupia. [...] Głupota przewala się po salach Luwru. Jedno z najgłupszych miejsc świata” (Gombrowicz, 2013, s. 765-766). „Głupota, jakiej doświadczam - i coraz silniej, w sposób coraz bardziej upokarzający - która mnie gniecie, osłabia bardzo się wzmogła odkąd zbliżyłem się do Paryża, najbardziej ogłupiającego z miast. Nie przypuszczam abym ja tylko czuł się w jej zasięgu; mnie się zdaje, że wszyscy biorący udział w wielkim marszu świadomości współczesnej nie zdołali zagłuszyć w sobie jej kroku towarzyszącego... jej przedzierania się zaroślami tuż, tuż... Zastanawiałem się i zastanawiam, jak ustalić Prawo, określające najzwięźlej tę sytuację specyficzną Ducha europejskiego [stawia kropkę nad ,"” Gombrowicz - W.K.]. Nie widzę nic innego, oprócz IM MĄDRZEJ, TYM GŁUPIEJ” (Gombrowicz, 2013, s. 889). „Kłamstwo nieprzerwanie nas drąży"... Muszę się zastrzec, że prawo im mądrzej, tym głupiej, formułuję bez odrobiny żartu. Nie, to tak naprawdę..." (Gombrowicz, 1992, s. 137). 
Czytamy u Mickiewicza:

„»Zaszło słońce«, wołają astronomy z wieży,

Ale dlaczego zaszło, nikt nie odpowiada;

Ciemności kryją ziemię i lud we śnie leży,

Lecz dlaczego śpią ludzie, żaden z nich nie bada"

(Dziady, cz. III, 61-64).

„W ostatnich latach francuski autor Yannick Haenel wydał w Paryżu książkę p.t. Jan Karski, która we Francji okazała się bestsellerem. Jej dwa pierwsze rozdziały mają charakter dokumentu, przedstawiającego losy tytułowego bohatera polskiego podziemia, który poinformował F.D. Roosevelta o okrucieństwach Holocaustu. Rozdział trzeci jest literacką fikcją. W tym rozdziale wyobrażony Karski odkrywa zaraz po wojnie, w muzeum w Nowym Yorku, obraz Rembrandta Jeździec polski. »Naziści ponieśli klęskę, [...], ale barbarzyństwo nie zostało przezwyciężone, choć wokół krzyczano tylko o tym [zwierza się fikcyjny narrator, Karski - W.K.] [...] Żołnierze polskiej armii wkroczyli do Berlina razem z Armią Czerwoną, a gdy miasto zostało podbite, Sowieci zwrócili się przeciwko Polakom. [...] Nikt nie miał zaznać wytchnienia, bo różnica między wojną a pokojem przestała istnieć, a zbrodnia zalała świat. Przez cały dzień chodziłem po Nowym Jorku, próbowałem się uspokoić. Właśnie wtedy po raz pierwszy zobaczyłem Jeźdźca polskiego. Jest to niewielkie, utrzymane w czerwonych i brunatnych tonach płótno [...]. Przedstawia młodzieńca jadącego o zmierzchu na białym koniu. Od razu spodobała mi się postawa tego chłopca, jego nieokrzesanie i szlachetność. Była w nim jakaś delikatność, ale i nieprzejednanie, i spokój, właściwy odpoczywającym wojownikom. [...] Pozwalam, by opromieniło mnie to ciepłe światło brązów, rudości, ten zielonoszary blask, który rozjaśnia cienie i czyni spojrzenie jeźdźca wyzywającym, a jednocześnie rozmarzonym. Zawsze metodycznie wszystko obserwuję: aksamitną czerwień spodni, detale szabli, łuku i kołczanu, ruch białego konia i ten pejzaż, który wygląda jak spalony żarem starych pól bitewnych, pejzaż zaklęty w czasie, podziwiam odcień ruiny w tle i tajemniczą barwę oczekiwania. Od razu spodobał mi się gest jeźdźca - właśnie ten gest lubię najbardziej. Ta pięść wsparta na biodrze - gest oficera, nonszalancja arystokraty" (Haenel, 2010, s. 146-147). Karski o obrazie, o jakim mowa, opowiedział swojej narzeczonej, uratowanej z Holocaustu Poli; i zaprosił ją do jego oglądania. „Jakim królestwem mógłby władać Jeździec polski?” (Haenel, 2010, s. 159) - zadaje pytanie. I odpowiada: „Nie rządziłby dawną Polską, lecz królestwem wewnętrznym, niemal niedostrzegalnym, królestwem bez ziemi i władzy, królestwem, które czyni wolnym każdego z nas” (Haenel, 2010, s. 159). „Cudzoziemcy, co nie mogli dość pojąć urządzenia Polski, utyskiwali nad ścieśnieniem władzy królewskiej. Jeden z nich mówił: wy Polacy nie macie króla. Wybacz, mamy króla, odparł nasz Polak, a u was, król 
was ma” (Lelewel, 1855, s. 465). Polacy „przejmując stron zachodnich etykietę przyodzieli ją wyrazem godności” (Lelewel, 1855, s. 279). W świecie wartości nie ma miejsca na kantowskie przed.

Pisze Kołakowski: „Kartezjańskie ego jest rodzajem czarnej dziury: potrafi wessać wszystko (z wyjątkiem alter-ego) i nic zeń się nie wymknie. Niewysławialne i niekomunikowalne, pojęciowo niekonstruowalne, zaiste może być zwane niczym (faktycznie, powiadają nam teraz w Oxfordzie, że słowo »ja«, choć ma znaczenie, pozbawione jest desygnatu)" (Kołakowski, 1990, s. 85). Ja to $J a$. Jeżeli tak jest, to trzeba mieć świadomość faktu, iż wyjścia poza to $J a$ nie ma. A to oznacza coś paradoksalnego. „Jeśli nic prawdziwego nie istnieje poza mną, ja sam jestem niczym" (Kołakowski, 1990, s. 30). Ja to świat; świat istnieje o tyle, o ile istnieje $J a$. Jednak tak rozumiane $J a$ znika. A to, w efekcie, oznacza, iż świat - świat „wartości” znika. Racjonalizm kartezjański okazuje się tu samowywracalny. Wysiłek człowieka nowożytnego, który na gruncie cogito chce dotrzeć do świata obiektywnych wartości, to przedsięwzięcie barona von Münchhausena... I nic tu nie daje program, który chce jednostce w tym wysiłku podnieść poprzeczkę. Tak właśnie zrobił Kant w Krytyce władzy sądzenia. Jest to jego pojęcie wzniostości (das Erhabene). Ta kategoria, z kolei, znalazła rozwinięcie w refleksji Friedricha Nietzschego. Jest to jego koncepcja nadczłowieka. Stawia pytanie Gombrowicz: „Nietzscheanizm i jego afirmacja życia? Ale Nietzsche nie miał najmniejszego wyczucia tych spraw, trudno wyobrazić sobie coś bardziej papierowego a nawet śmieszniejszego i w gorszym smaku niż jego nadczłowiek i jego młoda bestia ludzka, nie, nieprawda, nie pełnia ale właśnie niedostateczność, gorszość, niższość, niedojrzałość są właściwe temu co jeszcze jest młode, czyli żywe" (Gombrowicz, 2013, s. 227). Jest bowiem tak, iż „,złowiek jest istotą stworzoną do życia w sferze średniego ciśnienia, średnich temperatur. Znamy dziś chłód śmiertelny, znamy ogień żywy, ale zapomnieliśmy sekretów letniego wietrzyka, który orzeźwia, pozwala oddychać. Wolność! Na to aby być wolnym potrzeba nie tylko chcieć być wolnym - potrzeba chcieć być wolnym nie za bardzo" (Gombrowicz, 2013, s. 140). Prolegomena do wszelkiej przyszłej metafizyki, która będzie mogła wystapić jako nauka, to nic innego, jak tzw. światopogląd naukowy... A priori wszak może być wpisane w rozmaity kontekst; także w kontekst myśli totalitarnej. Jakie tam „czyste prawa cnoty”... I jaka tam „świadomość nieszczęśliwa”... Człowiek, to brzmi dumnie... I tak, i nie... Tu wystarcza virtus phaenomenon. A wyraża go „taniec polski”, „taniec” wokół „wartości”. One są, istnieją; rzeczywiście, realnie... Sapere aude! W archetypie kultury polskiej nic z tych rzeczy.

Wracając jeszcze raz do Tischnera: „Spróbujmy sobie przypomnieć [...] dzieła opisujące sarmacką melancholię. [...] Wydaje mi się jednak, że byłoby właściwiej posłużyć się tutaj stosunkowo rzadziej używanym słowem »rzewność«. [...] Rzewność jest swojska, polska. Jest dla melancholii tym, czym dźwięk dla tonu, kolor dla przestrzeni, fala dla płynącej wody" (Tischner, 1970, s. 1247). 
„Mówiłem sobie [zwierza się Karski - W.K.] trudno znieść to, co się teraz dzieje, ale jednocześnie istnieje coś ukrytego i dziewiczego, coś, co opiera się atakom i pozwala uwierzyć w światło. Tego majowego dnia czterdziestego piątego, gdy świat celebrował sam siebie, zrozumiałem, że ja zostałem z niego wykluczony i rodzi się we mnie pewna siła. [...] Znów byłem tylko ja i moja samotność, i znów miałem do niej zaufanie" (Haenel, 2010, s. 148). Rembrandt opowiada o „samotności”. Jednakże „przeczuwał, że ta samotność utkana jest nie tylko z nieszczęścia, że tkwi w niej pewien sekret, który chroni ją przed najgorszym [...]. Trzeba się dobrze przyjrzeć uśmiechowi jeźdźca, bo ten uśmiech rozprasza ciemności" (Haenel, 2010, s. 158-159). Na twarzy jeźdźca widać odblask świata „wartości”, tak, jak je pojmował Sokrates... „Ludzie, których nazywam Polakami, choć nie zawsze mają związki z Polską, stanowią mniejszość [twierdzi narrator Karski - W.K.]. Przez całe życie i ja należałem do mniejszości. Przy każdej okazji [...] moja myśl uświadamiała mi: należę do mniejszości. W gruncie rzeczy każdy Polak jest dla mnie kimś, kto właśnie tego doświadcza. Polak, niezależnie od kraju, w którym żyje, jest sam w sobie mniejszością" (Haenel, 2010, s. 169). Pola (popełniła samobójstwo) „była dla mnie ucieleśnieniem ducha awangardy, Nowego Jorku, Greenwich Village, a jednocześnie była Polską, czyli wieczną czułością" (Haenel, 2010, s. 158). Nie „wszystko wolno”! - jakby to $\mathrm{w}$ tym kontekście nie brzmiało absurdalnie; „wieczna czułość” i - znani w swoim czasie z okrucieństwa - lisowczycy... Wspomina Gombrowicz Argentynę: „Moi przygodni towarzysze [...]. Kiedyś spacerując z jednym z nich po ulicy [...] powiedziałem, że jeść mi się chce [...] - Nic, powiedział, nie przejmuj się, mam trupa, starczy dla dwóch. Wsiedliśmy do tramwaju i pojechaliśmy na przedmieście, do jakiegoś domku w dzielnicy robotniczej, gdzie rzeczywiście nieboszczyk, [...] leżał w trumnie, obłożony kwiatami [...]. Pomodliwszy się przeszliśmy do sąsiedniego pokoju, gdzie był poczęstunek dla żałobników, bufet, kanapki, wino, jedliśmy... [...]. To młode, nieskończenie eleganckie, jedzenie trupa urosło mi do jakiegoś bardzo głębokiego symbolu owych czasów... to zajadanie trupa $z$ młodym, świetnym, apetytem... [...]. I cała to moje „naturalność", to była w końcu tylko sztuczność i gra... ale gra najdonioślejsza, najwspanialsza, jaką mogłem wieść ze sobą samym. Dzięki temu paradoksalnemu rozmiłowaniu w upadku przetrwałem wojnę i nędzę zwycięsko. [...] Ale burżuazyjna ostrożność mnie nie opuszczała i nigdy nie dałem się wciągnąć w przedsięwzięcia bardziej ryzykowne" (Gombrowicz, 1992, s. 82-83). Polska... „zjadanie trupa” nowożytności...

$* * *$

A więc powtórzmy tytułowe pytanie: Jest problem z naszym archetypem, czy go nie ma? Przyjmując, że go nie ma, przedstawiona refleksja była o niczym. Nie ma żadnej „zagadki dziejów Polski”. Jesteśmy w Europie; demokra- 
cja, to demokracja, Oświecenie, to Oświecenie; „rozum” to „rozum”... A jednak naoczna obserwacja życia publicznego w Polsce - chciałoby się wręcz powiedzieć: intuicja - nasuwa myśl, iż coś tu „nie gra”..., ,pospolitość skrzeczy”... Trzeba zatem sięgnąc do archetypu. Problem w tym, iż refleksja nad archetypem kultury, każdej kultury, nie mieści się w kategoriach ściśle rozumianej politologii. I nie jest to język bez reszty filozofii; choć dotyczy materii par excellence filozoficznej. Jest to świat metafory. A to oznacza, iż trudno tu o jakąś precyzję i weryfikowalne tezy. I tak to można archetyp kultury polskiej widzieć jako sarmacki świat „,melancholii”; i w nim upatrywać źródła wspomnianej „pospolitości”... Można jednak - idąc tropem J. Tischnera - odkryć pod warstwą „melancholii” coś głębszego; „rzewność” (czy „wieczną czułość”). Jeżeli już podejmuje się tego typu refleksję, to, jak widać, wszystko tu jest niejasne; i w swej wymowie - niejednoznaczne. A więc „swego szukać” czy nie? Jest to, jak wolno sądzić, kwestia cały czas otwarta.

\section{Bibliografia}

Adamus J., (1958). Polska teoria rodowa. Łódź-Wrocław: Zakład Narodowy im. Ossolińskich.

Baczko B. (1964). Rousseau. Samotność i wspólnota. Warszawa: Państwowe Wydawnictwo Naukowe

Brzozowski, S. (1983). Legenda Młodej Polski; reprint wydania II z 1910 roku, Kraków-Wrocław: Wydawnictwo Literackie.

Gombrowicz, W. (1992). Dziennik 1967-1969. Rozmowy z Dominikiem de Roux. Kraków: Wydawnictwo Literackie.

Gombrowicz, W. (2013). Dziennik 1953-1969. Kraków: Wydawnictwo Literackie.

Haenel, Y. (2010). Jan Karski. Przeł. M. Kamińska-Maurugeon. Kraków: Wydawnictwo Literackie.

Hobbes Th., (1954). Lewiatan. Przeł. C. Znamierowski. Warszawa: Państwowe Wydawnictwo Naukowe.

Kant, I. (1953). Uzasadnienie metafizyki moralności. Przeł. M. Wartenberg. Przekł. przejrzał R. Ingarden. Warszawa: Państwowe Wydawnictwo Naukowe.

Kant, I. (1993a). Prolegomena do wszelkiej przyszłej metafizyki, która będzie mogła wystapić jako nauka. Przekł. B. Bornsteina na nowo oprac. J. Suchorzewska. Warszawa: Państwowe Wydawnictwo Naukowe.

Kant, I. (1993b). Religia w obrębie samego rozumu. Przeł. A. Bobko. Kraków: „Znak”.

Kant, I. (1995). Co to jest oświecenie ? W: Idem, Przypuszczalny początek ludzkiej historii i inne pisma historiozoficzne. Przeł. M. Żelazny, I. Krońska, A. Landman. Toruń: Comer. 
Kant, I. (2002). Krytyka praktycznego rozumu. Przeł. B. Bornstein. Kęty: „Antyk”. Kołakowski L., (1990). Horror metaphysicus. [Przeł. M. Panufnik]. Warszawa: Res Publica.

Kołakowski, L. (1988). Główne nurty marksizmu. Powstanie - rozwój - rozkład. Londyn: Wydawnictwo Aneks.

Ksenofont, (1967). Wspomnienia o Sokratesie. W: Idem, Pisma sokratyczne. Przeł. i wstępem poprzedził L. Joachimowicz. Warszawa: Państwowe Wydawnictwo Naukowe.

Lelewel, J. (1855). Uwagi nad dziejami Polski i ludu jej. W: Polska, dzieje i rzeczy jej rozpatrywane. Poznań: J. K. Żupański.

Lelewel, J. (1964). Dzieła. T. 2 (2). Pisma metodologiczne, Warszawa: Państwowe Wydawnictwo Naukowe.

Lelewel, J. (1864). Mowy i pisma polityczne. Poznań: J. K. Żupański.

Locke, J. (1992). Dwa traktaty o rzadzie. Przeł. [z ang.], wstępem i komentarzem opatrzył Z. Rau; przekł. przejrzał A. Czarnota. Warszawa: Wydawnictwo Naukowe PWN.

Manent, P. (1994). Intelektualna historia liberalizmu. Przeł. M. Miszalski. Kraków: „Arcana".

Marks, K. (1968). Posłowie do wydania drugiego. W: Idem, Dzieła. T. 23: Kapitat. Warszawa: Książka i Wiedza.

Rousseau, J.J. (1956). Rozprawa o pochodzeniu i podstawach nierówności między ludźmi. W: Idem, Trzy rozprawy o filozofii społecznej. Przeł. H. Elzenberg. Warszawa: Państwowe Wydawnictwo Naukowe.

Rousseau, J.J. (2002). Umowa społeczna. Przeł. A. Peretiatkowicz. Kęty: „Antyk”.

Tischner, J. (1970). Chochoł sarmackiej melancholii. Znak, 196.

Walicki, A. (1966). Marksizm i skok do królestwa wolności. Dzieje komunistycznej utopii, Warszawa: Wydawnictwo Naukowe PWN.

Witkiewicz, S.I. (1979). Niemyte dusze. W: Idem, Narkotyki; Niemyte dusze. Warszawa: Państwowy Instytut Wydawniczy. 